\title{
The Haemagglutination Inhibitor in Edible Bird-Nest: its Biological and Physical Properties
}

\author{
By F. BIDDLE AND G. BELYAVIN \\ Department of Bacteriology, University College Hospital Medical School, \\ University Street, London, W.C. 1
}

(Received 17 July 1962)

\begin{abstract}
SUMMARY
This paper describes an investigation into the degree of homogeneity of the substance termed collocalia mucoid obtained from edible bird-nest. This material is a potent inhibitor of influenza virus haemagglutination and additional information is given here regarding its ability to neutralize infectivity. The crude material obtained by simple extraction was found to contain three components differing in molecular size and biological activity. Some separation of these was obtained by means of preparative ultracentrifugation. The slowest moving component differed from the others not only physically, but also in having much less inhibitor activity.
\end{abstract}

\section{INTRODUCTION}

Various animal sera and secretions contain substances which are able to inhibit haemagglutination by influenza viruses. These inhibitors have been divided into $\alpha$ and $\beta$ types on the basis of their thermostability, their sensitivity to Vibrio cholerae neuraminidase, and the strain of influenza virus most susceptible to their action (Smith, Westwood \& Belyavin, 1951). In more recent years a third class of inhibitor present in certain animal sera and characterized by its specific activity against A2 virus strains has been described (Shimojo, Sugiura, Akao \& Enomoto, 1959; Cohen \& Belyavin, 1959). This third type of inhibitor as it occurs in horse serum has been shown to be a potent infectivity-neutralizing substance in addition to its effectiveness as a simple haemagglutination inhibitor (Cohen \& Belyavin, 1959). Other naturally occurring neutralizing inhibitors have been described, notably urinary mucoprotein (Tamm \& Horsfall, 1952). The great variation in biological activity shown by these substances, both with regard to the type of virus predominantly inhibited and their ability to neutralize infectivity as well as haemagglutination, makes the chemical structure of these materials of great interest and importance.

Some work attempting to relate chemical structure to biological properties has already been published (Gottschalk \& Fazekas de St Groth, 1960). Investigations in this direction are largely dependent upon the isolation of these inhibitors in a chemically homogeneous form. This is a technically difficult and time-consuming process where isolation of active inhibitor from crude serum is concerned. It is therefore of great interest to find other inhibitory substances present in fairly simple biological secretions from which they can be fractionated in a relatively pure form with comparative ease. Amongst these is a substance obtained from edible bird-nest 
by Howe, Lee \& Rose (1960) and called by them collocalia mucoid. It was decided to include this substance in a study of various inhibitors, but as a preliminary to the detailed investigation of the biological and chemical properties of collocalia mucoid it was necessary to establish the degree of homogeneity of material obtained by the method of Howe, Lee \& Rose (1961). The results reported in this paper are concerned mainly with this question of homogeneity, but additional information is presented about the inhibitor properties of the material and in particular its ability to neutralize active virus.

\section{METHODS}

Nitrogen estimations. The nitrogen content was determined by the method of Paul (1958) with certain modifications. Test material was digested for $40 \mathrm{~min}$. with $\mathbf{0 . 2} \mathrm{ml}$. of $50 \% \mathrm{H}_{2} \mathrm{SO}_{4}$ containing $1 \%$ selenium dioxide. After digestion the tubes were cooled and $1.75 \mathrm{ml}$. of double-distilled water added followed by $5 \mathrm{ml}$. of alkaline Nessler solution. The tubes were left to stand for $20 \mathrm{~min}$. and the intensity of the resulting colour read in the Unicam S.P. 500 spectrophotometer at $490 \mathrm{~m} \mu$ using a $1 \mathrm{~cm}$. optical cell. Samples of a standard solution of $\left(\mathrm{NH}_{4}\right)_{2} \mathrm{SO}_{4}$ containing $20 \mu \mathrm{g} . \mathrm{N} / \mathbf{0 . 5} \mathrm{ml}$. were included as controls in every test. As the extinction of nesslerized digest was linear with $N$ concentration within a range of 5-80 $\mu \mathrm{g} . \mathrm{N} /$ $0.5 \mathrm{ml}$., it was usual to dilute the material so that its nitrogen content fell within these limits. When necessary a rough preliminary test was carried out to give an idea of the dilution required.

Sialic acid ( $N$-acetylneuraminic acid). The thiobarbituric acid method of Warren (1959) was used. The method was standardized by comparing the results obtained with a purified mucopolysaccharide from ovarian cyst fluid (Pusztai \& Morgan, 1961), containing an accurately known amount of sialic acid. As reported originally by Warren the extinction of the chromophore at $549 \mathrm{~m} \mu$ was linear over the range 0.01-0.05 $\mu$ mole.

Chromatography on calcium phosphate. The method of calcium phosphate chromatography used was that described by Tiselius, Hjertew \& Levin (1956). The test material was adsorbed to Brushite columns at pH 8 in $0.01 \mathrm{M}$-phosphate buffer; gradient elutions were then performed with phosphate buffers of increasing molarity but constant $\mathrm{pH}$ value. Samples $(10 \mathrm{ml}$.) were collected and tested for protein by measuring their extinction value at $280 \mathrm{~m} \mu$ and for their inhibitor content against heated Rов (B type) virus.

DEAE-cellulose chromatography. Columns of DEAE-cellulose anionic form (Whatman DE 50 powder) were prepared according to the method of Sober, Gutter, Wycoff \& Peterson (1956). The test material was adsorbed on to the columns at $\mathrm{pH} 6.8$ and gradient elutions performed with various solutions as indicated in the text. The quantities of eluting buffers employed were adjusted so that small amounts of test material could be used. The volumes of fluid in both the mixing vessel and the charging vessel were each $50 \mathrm{ml}$. Samples of $3 \mathrm{ml}$. were collected and their protein content estimated by measuring their extinction values at $28 \mathrm{~m} \mu$.

Ultracentrifugation. Ultracentrifugation studies were carried out on an air-driven ultracentrifuge of the Beam and Pickels type, and also on a Spinco Model E. Material for analysis was taken up in $\mathbf{0 . 0 5} \mathrm{M}$-phosphate buffer and sedimentation 
constants were calculated for water at $20^{\circ}$ and extrapolated to zero concentration. We are very glad to acknowledge here our great indebtedness to Professor Baldwin and Dr E. Crook of the Biochemistry Department, University College London, and Dr K. Sanders of the M.R.C. Virus Research Unit, Carshalton, for placing their ultracentrifuge facilities so generously at our disposal.

Electrophoresis. Electrophoresis studies were carried out for us by $\mathrm{Dr}$ M. Rosemeyer of the Biochemistry Department, University College London, with a standard Tiselius apparatus. The details of the conditions used are given later.

Viruses. Three prototype influenza strains regularly used in this laboratory for the detection of different types of inhibitory activity were chosen. For detecting $\beta$ activity, strain ASH, a representative $A 1$ strain, isolated in 1953 was used. The type $B$ strain вов isolated in this laboratory in 1955 was used after heating at $56^{\circ}$ for $30 \mathrm{~min}$. for detecting $\alpha$ activity. In additional tests the A2 strain A/Singapore $\mathrm{w}$ was included to test for $\gamma$ activity (Cohen \& Belyavin, 1959). From time to time other strains were used as indicated. Each strain was maintained by allantoic passage in chick embryos. Infected allantoic fluids were prepared from seed viruses stored at $-65^{\circ}$ by inoculation of 10 - to 12 -day embryos with $0.2 \mathrm{ml}$. of seed diluted $10^{-3}$ in nutrient broth containing penicillin 2500 units $/ \mathrm{ml}$., and streptomycin $3000 \mu \mathrm{g} . / \mathrm{ml}$. After incubation at $35^{\circ}$ for $72 \mathrm{hr}$. the eggs were chilled overnight and allantoic fluids harvested, pooled and stored at $4^{\circ}$ until required.

Haemagglutination $(H A)$ and haemagglutination inhibition $(H I)$ titrations. Titrations were done by the photoelectric densitometer method of Hirst \& Pickels (1942) modified by Belyavin, Westwood, Please \& Smith (1951). Titres were obtained from densitometer readings by the use of a nomogram (Lim, 1954) for $50 \%$ endpoint interpolations.

Neutralization tests in eggs. Serial dilutions of the test material in penicillin + streptomycin broth were mixed with equal volumes of the virus diluted to contain 1000 EID 50 (egg infective doses) in $0.2 \mathrm{ml}$., and the mixtures held at $37^{\circ}$ for $30 \mathrm{~min}$. Groups of six 11-day chick embryos were inoculated with $\mathbf{0 . 2} \mathrm{ml}$. volumes of each mixture. In parallel, the virus challenge dose was checked by a standard infectivity titration. After incubation for $72 \mathrm{hr}$. the eggs were chilled, harvested and each allantoic fluid tested for virus by haemagglutination in WHO plastic trays; $50 \%$ infectivity end-points were calculated by the method of moving averages (Thomson, 1947).

Neuraminidase (receptor destroying enzyme; RDE) prepared from Vibrio cholerae by the method of Burnet \& Stone (1947) was purified by one cycle of adsorption and elution with human group $\mathrm{O}$ red cells.

Treatment of inhibitor with neuraminidase. Solutions $\mathbf{0 . 2} \%$ of lyophilized inhibitor were prepared in calcium acetate buffered saline $(\mathrm{pH} 6 \cdot 2)$. These were diluted with an equal volume of RDE (neuraminidase) diluted one in two in calcium acetate buffered saline. The mixtures were held at $37^{\circ}$ for $4 \mathrm{hr}$. and then at $56^{\circ}$ for $30 \mathrm{~min}$. to inactivate the residual active enzyme. Controls consisted of $(a)$ the $0 \cdot 2 \%$ solution of inhibitor diluted one in two in calcium acetate buffered saline, and heated in parallel with the test solutions, and $(b)$ a similar dilution which was unheated.

Preparing collocalia mucoid. The method used for preparing collocalia mucoid was essentially as described by Howe, Lee $\&$ Rose (1961) except that the crude birdnest material was soaked in cold water before extraction at $62^{\circ}$. This was done to 
wash out any free sialic acid from the crude material. The crude bird-nest substance was purchased from a dealer and it was noted that two grades of material (referred to subsequently as first and second quality) were retailed. Comparative tests showed that there was a considerable difference in yield of inhibitory activity between the two grades and that they also differed in respect of the 'free' sialic acid content (Table 1). As a result care was taken to use only 'first grade' material for all

Table 1. Comparison of sialic acid content and haemagglutination inhibition (HI) activity of distilled water extracts prepared from 'first 'and 'second' quality edible birdnest material

Extractions performed for different times at $62^{\circ}$ on a $10 \%$ suspension of crude material.

\begin{tabular}{|c|c|c|c|c|c|}
\hline Material & $\begin{array}{c}\text { Total } \\
\text { sialic acid } \\
(\mu \mathrm{g} \cdot / \mathrm{ml} .)\end{array}$ & $\begin{array}{l}\text { Free } \\
\text { sialic acid } \\
(\mu \mathrm{g} \cdot / \mathrm{ml} .)\end{array}$ & $\begin{array}{c}\text { Combined } \\
\text { sialic acid } \\
(\mu \mathrm{g} . / \mathrm{ml} .)\end{array}$ & $\begin{array}{l}\text { HI titre } \\
\text { v. heated } \\
\text { ROB }\end{array}$ & $\begin{array}{c}\text { Specific } \\
\text { activity } \\
\text { HI } / \mu \mathrm{g} \text {. } \\
\text { sialic acid } \\
\text { combined }\end{array}$ \\
\hline $\begin{aligned} & \text { 2nd quality } \frac{1}{2} \mathrm{hr} \text {. extract } \\
& 1 \mathrm{hr} \text {. extract } \\
& 4 \mathrm{hr} \text {. extract }\end{aligned}$ & $\begin{array}{l}320 \\
420 \\
\text { n.t. }\end{array}$ & $\begin{array}{l}300 \\
300 \\
\text { n.t. }\end{array}$ & $\begin{array}{r}20 \\
120 \\
\text { n.t. }\end{array}$ & $\begin{array}{r}96 \\
250 \\
425\end{array}$ & $\begin{array}{l}4 \cdot 8 \\
2 \cdot 1 \\
-\end{array}$ \\
\hline $\begin{array}{ll}\text { 1st quality } & 2 \mathrm{hr} \text {. washing* } \\
& 2 \mathrm{hr} \text {. extract } \\
& 4 \mathrm{hr} \text {. extract }\end{array}$ & $\begin{array}{r}\text { n.t. } \\
720 \\
\mathbf{3 , 3 6 0}\end{array}$ & $\begin{array}{l}107 \\
205 \\
303\end{array}$ & $\begin{array}{r}\text { n.t. } \\
\mathbf{5 1 5} \\
\mathbf{3 , 0 5 7}\end{array}$ & $\begin{array}{r}461 \\
>10,240 \\
>10,240\end{array}$ & $\begin{array}{r}-\overline{ } \\
>20 \cdot 0 \\
>3 \cdot 0\end{array}$ \\
\hline
\end{tabular}

* At room temperature; n.t. = not tested.

Table 2. Haemagglutination inhibitor (HI) concentration in successive extracts of crude edible bird-nest at $\mathbf{6 2}^{\circ}$

$\begin{array}{lc}\text { Material* } & \begin{array}{c}\text { HI titre v. } \\ \text { heated ROB }\end{array} \\ \text { 1st extract } & 4150 \\ \text { 2nd extract } & 2998 \\ \text { 3rd extract } & 5263 \\ \text { * At a concentration of } \mathbf{2 . 5} \%\end{array}$

subsequent preparative work. It is interesting to note that the 'second grade' material was obviously different in appearance, being somewhat darker in colour, and also being evidently contaminated with feathers and other extraneous matter.

Repeated extractions of a given batch of material showed continued yield of inhibitor (Table 2) and multiple extractions were therefore adopted as a standard procedure. Extractions at a lower temperature yielded only very little inhibitor. The final method of preparation adopted was as follows. Powdered crude bird-nest (12 g.) was soaked in distilled water $(200 \mathrm{ml}$.) for $2 \mathrm{hr}$. at room temperature on two successive occasions. The washings were discarded and the solid material then extracted at $62^{\circ}$ three times in succession, each extraction lasting $4 \mathrm{hr}$., with $1000 \mathrm{ml}$. distilled water in the first and $500 \mathrm{ml}$. in each of the other extractions. Between extractions the solid material was separated by filtration through Whatman No. 1 filter paper on a Buchner funnel; finally the pooled extracts were lyophilized. The yield under these conditions was about $100 \mathrm{mg}$. lyophilized powder/g. crude bird-nest material extracted. The fluffy white material obtained on lyophilization 
was initially readily soluble in water, but on storage some deterioration occurred. The substance became less soluble and there was a loss of specific inhibitory activity. Even the fresh material was easily precipitated from solution by the addition of electrolytes when these exceeded a certain concentration.

\section{RESULTS}

\section{Homogeneity of crude collocalia mucoid}

Calcium phosphate chromatography. Crude lyophilized extract (10-20 mg.) was made up in $10 \mathrm{ml}$. of $0.01 \mathrm{M}$-phosphate buffer ( $\mathrm{pH} 8.0$ ), and applied to calcium phosphate columns $10 \times 3 \mathrm{~cm}$. Gradient elution of preparations made from the
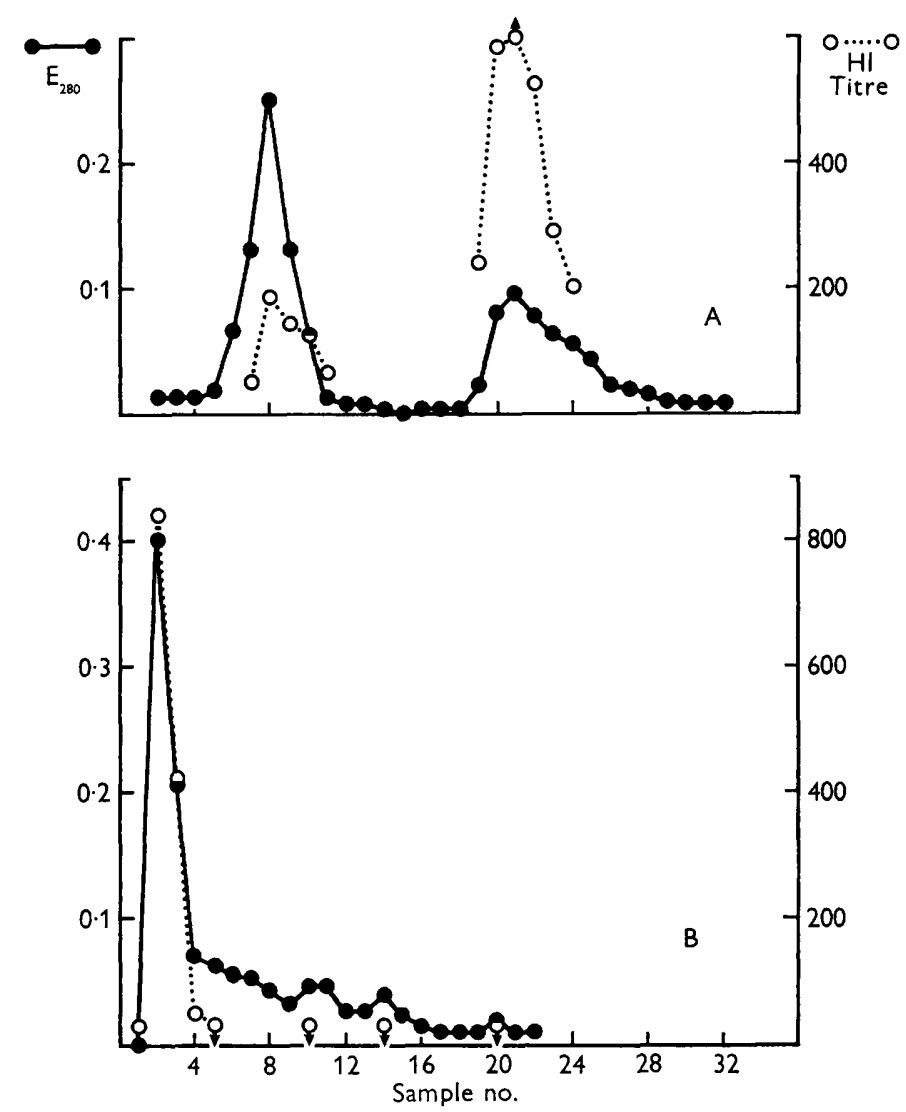

Fig. 1A. Calcium phosphate chromatography of a crude extract of collocalia mucoid showing separation into two components.

Fig. 1B. Calcium phosphate chromatography of crude collocalia mucoid showing the usual pattern obtained, consisting of a single component only.

original batch of bird-nest yielded a chromatographic pattern characterized by two clear-cut protein peaks (Fig. 1 A). Inhibition tests showed that the second peak had a higher specific activity/mg. nitrogen than the leading peak. This was confirmed by stepwise elution of the same initially ophilized preparations, but every attempt to 
concentrate and lyophilize the second active peak material led to the isolation of a completely insoluble and apparently denatured substance. Four consecutive extracts from the same initial batch of bird-nest material yielded this chromatographic pattern, irrespective of the calcium phosphate preparation used. All subsequently purchased batches of bird-nest material extracted by the procedure described above, however, have yielded a single dominant protein peak, with a corresponding inhibitory pattern (Fig. 1B). The specific inhibitory activity of this peak

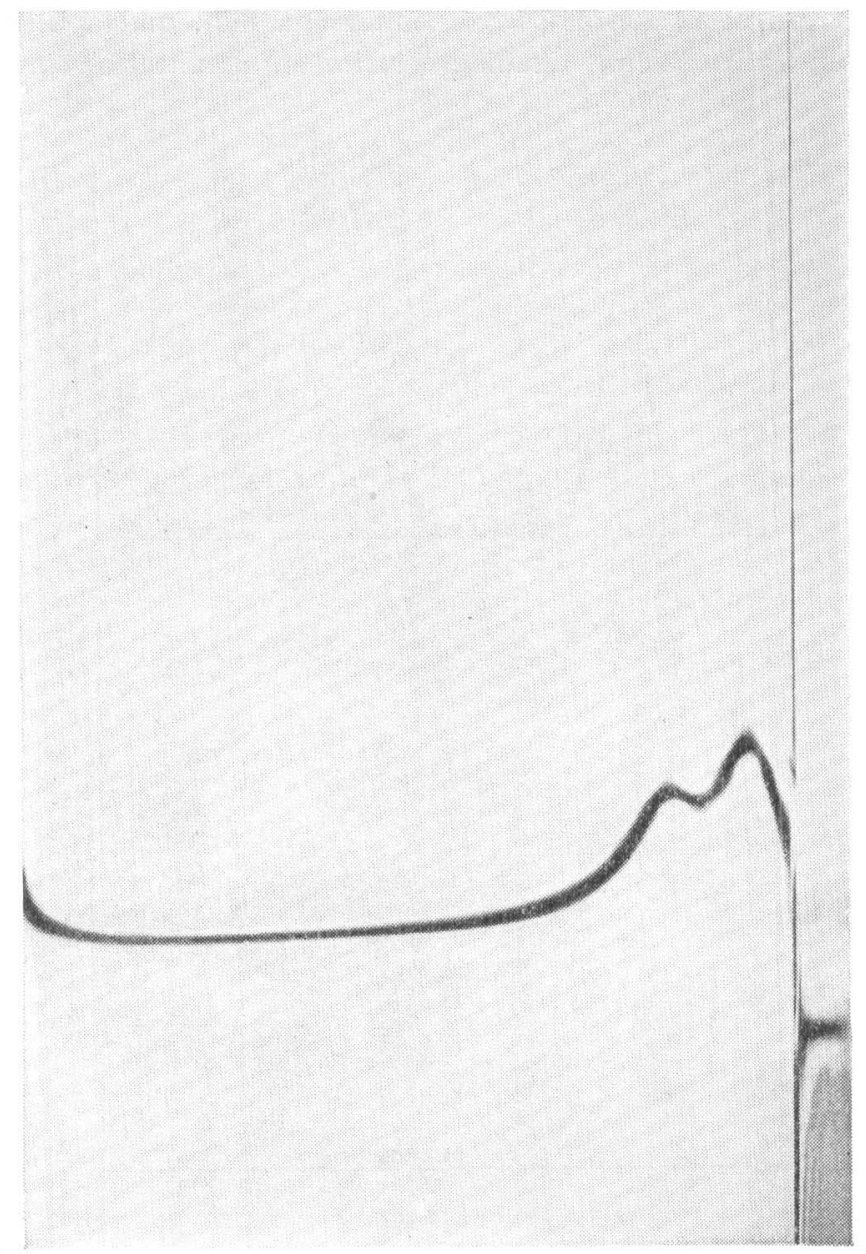

Fig. 2. Ultracentrifuge pattern of crude collocalia mucoid showing early separation of fast-moving (20S) component. (4 min. after reaching maximum speed-50,740 rev./min.) Sedimentation towards left.

was not markedly different either from the original starting material or from the first peak obtained in the earlier chromatograms. As this single peak was evidently due to material not adsorbing on the column, it was clear that no resolution of the crude material was being obtained by this system. 
$D E A E$-cellulose chromatography. Since calcium phosphate did not resolve collocalia mucoid it was decided to try DEAE-cellulose columns. Work in this laboratory has indicated that Brushite columns are cationic and so it was considered possible that an anionic exchanger might affect resolution.

Crude collocalia mucoid (100 mg.) was dissolved in $10 \mathrm{ml}$. 0.01 M-phosphate

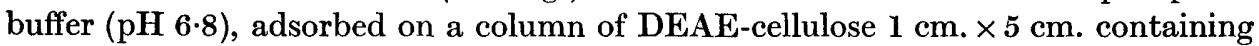
2.5 g. dry DEAE-cellulose. The following gradients were then used in succession:

(1) to $0.02 \mathrm{M}$-phosphate buffer ( $\mathrm{pH} 6.8$ ); (2) to $0.05 \mathrm{M}-\mathrm{NaH}_{2} \mathrm{PO}_{4}+0.05 \mathrm{M}-\mathrm{NaCl}$; (3) to $0 \cdot 1 \mathrm{M}-\mathrm{NaCl} ;(4)$ to $0 \cdot 2 \mathrm{M}-\mathrm{NaCl}$. None of the adsorbed material was recovered in the effluent at any stage of the eluting gradients. Two explanations are possible. The collocalia mucoid might have been largely denatured by the electrolyte in the eluting buffers, and thus failed to penetrate the column. It is also possible that, due to its high negative charge, it formed a strong union with the positively charged DEAE-cellulose and thus remained adsorbed. As the method did not seem very promising, this technique was not pursued any further at this stage.

Analytical ultracentrifugation. Examination of the crude material in the analytical ultracentrifuge showed two well marked and easily separable peaks (Fig. 2). The ammonium sulphate precipitated material and the lyophilized concentrate of the single peak isolated chromatographically yielded a similar pattern. Later studies showed that with prolonged centrifugation at maximum speed the slow-moving component could be resolved into two further peaks. It was clear that at least three physically distinguishable components were present in the crude extract of collocalia mucoid and the sedimentation constants of these were calculated to be $1.4 \mathrm{~S}, 4.7 \mathrm{~S}$ and $20 \mathrm{~S}$, respectively (the $1.4 \mathrm{~S}$ value is calculated from a run at one concentration only). Preliminary examination of the material obtained by low temperature extraction showed it to be comparable in sedimentation velocity to the $1 \cdot 4 \mathrm{~S}$ component.

Electrophoresis. The crude extract was studied in the Tiselius electrophoresis apparatus. Solutions were prepared in 2-amino-2-hydroxymethylpropane-1,3-diol

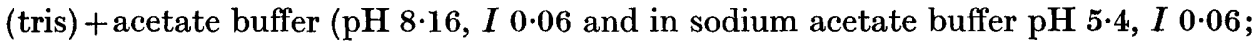
with the former solution a current of $1.7 \mathrm{~mA}$ was used, and with the latter a current of $2.6 \mathrm{~mA}$. Owing to the relative insolubility of collocalia mucoid the concentrations achieved were not very great, and after about $3 \mathrm{hr}$. the effects of diffusion caused marked blurring of the migrating boundaries. The duration of the run therefore was confined to this period; but within this time only a single peak was seen and this migrated rapidly towards the anode. The rapid movement of the material towards the anode was consistent with the possession of a high negative charge from the presence of sialic acid groupings, as is known to be the case with red blood cells.

\section{Attempts at fractionation}

Ammonium sulphate precipitation. Precipitation with ammonium sulphate gave a dense white precipitate which was easily soluble in water and which contained all the activity of the crude extract. On ultracentrifugation the ammonium sulphate precipitated material still showed two peaks and the specific activity did not differ significantly from that of the original (Table 3). This was confirmed by the fact that both the ammonium sulphate precipitate and the original material each contained about $10 \%$ sialic acid, indicating no essential difference between them. 
Ethanol fractionation. Ethanol precipitation was tried as a further means of purification and at $75 \%(\mathrm{v} / \mathrm{v})$ ethanol a dense white precipitate was obtained containing a substantial amount of haemagglutination-inhibition activity. A formal experiment was conducted in which potassium acetate was added to the crude extract in different proportions as has been used for the precipitation of mucoid substances (Pusztai \& Morgan, 1961). Ethanol was added at $4^{\circ}$ and the precipitate, if any, separated by centrifugation and taken up in a volume of water equal to that of the original. It was then tested for $\mathrm{HI}$ activity and the results show (Table 4) that the specific activity of the ethanol precipitate was no greater than that of the original. Comparison of the specific activities of the control preparations at the different concentrations of potassium acetate shows the deleterious effect of this salt on collocalia mucoid. Subsequent work has shown that this material can be precipitated from solution by a variety of electrolytes. Even in the absence of salts, however, the ethanol precipitate was so easily denatured that concentration was impossible, thus precluding further tests at this stage.

Table 3. Total nitrogen, haemagglutination inhibitor potency $(H I)$ and specific activity of crude extracts and ammonium sulphate $(\mathrm{AmS})$ precipitates prepared from different batches of bird-nest material (all compared as $0.1 \%$ solutions of lyophilized preparations)

\begin{tabular}{|c|c|c|c|c|}
\hline $\begin{array}{c}\text { Batch } \\
\text { of nest } \\
\text { material }\end{array}$ & Preparation & $\begin{array}{c}\text { Total } \\
\text { nitrogen } \\
(\mu \mathrm{g} . / \mathrm{ml} .)\end{array}$ & $\begin{array}{c}\text { HI titre } \\
\text { v. } \\
\text { heated nos }\end{array}$ & $\begin{array}{l}\text { Specific } \\
\text { activity } \\
\mathrm{HI} / \mu \mathrm{g} . \\
\mathrm{N} / \mathrm{ml} \text {. }\end{array}$ \\
\hline $\mathbf{A}^{*}$ & $\begin{array}{l}\text { Crude extract } \\
\text { AmS ppt. }\end{array}$ & $\begin{array}{l}110 \\
110\end{array}$ & $\begin{array}{l}1856 \\
1385\end{array}$ & $\begin{array}{l}17 \\
14\end{array}$ \\
\hline B & $\begin{array}{l}\text { AmS ppt. (1) } \\
\text { AmS ppt. (2) }\end{array}$ & $\begin{array}{l}110 \\
110\end{array}$ & $\begin{array}{l}1033 \\
1536\end{array}$ & $\begin{array}{r}9 \\
14\end{array}$ \\
\hline C & $\begin{array}{l}\text { Crude extract (1) } \\
\text { Crude extract (2) } \\
\text { Crude extract (3) } \\
\text { AmS ppt. (1) } \\
\text { AmS ppt. (2) }\end{array}$ & $\begin{array}{r}110 \\
110 \\
110 \\
87 \\
88\end{array}$ & $\begin{array}{r}1997 \\
2200 \\
1530 \\
1530 \\
973\end{array}$ & $\begin{array}{l}19 \\
20 \\
19 \\
17 \\
11\end{array}$ \\
\hline D & $\begin{array}{l}\text { Crude extract (1) } \\
\text { AmS ppt. } \\
\text { Crude extract (2) }\end{array}$ & $\begin{array}{l}92 \\
73 \\
87\end{array}$ & $\begin{array}{l}1011 \\
1120 \\
1472\end{array}$ & $\begin{array}{l}11 \\
15 \\
17\end{array}$ \\
\hline
\end{tabular}

* The only preparation yielding two peaks on calcium phosphate chromatography.

Fractionation by ultracentrifugation. An attempt was made to separate the three physically different components of collocalia mucoid by using the Spinco Model L preparative ultracentrifuge. Solutions of the material were centrifuged at $100,000 \mathrm{~g}$ (number 40 rotor) for periods of 2 and $6 \mathrm{hr}$. Examination of the $2 \mathrm{hr}$. supernatant fluid in the analytical ultracentrifuge did not detect any residual fast-moving (20S) component. The sialic acid, nitrogen and inhibitor values of the 2 and $6 \mathrm{hr}$. supernatant fluids were then compared with those of the original material before centrifugation (Table 5). The significance of these results will be discussed later, but certain features may be noted here. The lower specific activity of both the original material and the supernatant fluid in one experiment (Expt. 5, Table 5) was the result of storage of the mucoid, as discussed previously. The most significant feature of the results 
obtained is that after centrifuging for $6 \mathrm{hr}$. the residual supernatant fluid still contained about one-quarter to one-third of the nitrogen and sialic acid of the original, but the corresponding inhibitory activity had been decreased to less than one-tenth.

Table 4. Results of ethanol precipitation of crude bird-nest extract and the effect of adding potassium acetate on the specific activity

\begin{tabular}{|c|c|c|c|c|}
\hline $\begin{array}{c}\text { Ethanol } \\
\text { concentration } \\
(\mathrm{v} / \mathrm{v})\end{array}$ & $\begin{array}{c}\text { K acetate } \\
\text { added } \\
(\%)\end{array}$ & $\begin{array}{c}\text { HI titre } \\
\text { v. } \\
\text { heated RoB }\end{array}$ & $\underset{\text { (precipitate) }}{\mu \mathrm{g} . \mathrm{N} / \mathrm{ml} .}$ & $\begin{array}{c}\text { Specific } \\
\text { activity } \\
\mathrm{HI} / \mu \mathrm{g} . \mathrm{N} / \mathrm{ml} .\end{array}$ \\
\hline $\begin{array}{l}\mathbf{2 5} \% \\
\mathbf{5 0} \% \\
\mathbf{7 5} \% \\
\text { Control }\end{array}$ & 0.5 & $\begin{array}{r}<80 \\
<80 \\
966 \\
1120\end{array}$ & $\begin{array}{l}17 \cdot 5 \\
16 \\
80 \\
90\end{array}$ & $\begin{array}{r}<5 \\
<5 \\
12 \\
12\end{array}$ \\
\hline $\begin{array}{l}25 \% \\
50 \% \\
75 \% \\
\text { Control }\end{array}$ & $1 \cdot 0$ & $\begin{array}{l}120 \\
320 \\
720 \\
515\end{array}$ & $\begin{array}{l}40 \\
58 \\
85 \\
90\end{array}$ & $\begin{array}{l}3 \\
5 \\
9 \\
6\end{array}$ \\
\hline $\begin{array}{l}\mathbf{2 5} \% \\
\mathbf{5 0} \% \\
\mathbf{7 5} \% \\
\text { Control }\end{array}$ & $2 \cdot 0$ & $\begin{array}{l}126 \\
189 \\
390 \\
890\end{array}$ & $\begin{array}{r}58 \\
60 \\
60 \\
115\end{array}$ & $\begin{array}{l}2 \\
3 \\
7 \\
8\end{array}$ \\
\hline Control & nil & 1574 & 105 & 15 \\
\hline
\end{tabular}

Table 5. Results of centrifuging crude collocalia mucoid extracts at $100,000 \mathrm{~g}$ for different periods

\begin{tabular}{|c|c|c|c|c|c|c|c|}
\hline Expt. & $\begin{array}{l}\text { Prepa- } \\
\text { ration }\end{array}$ & $\begin{array}{c}\text { Concen- } \\
\text { tration } \\
(\%)\end{array}$ & $\begin{array}{c}\text { Time of } \\
\text { centrifuging } \\
\text { (hr.) }\end{array}$ & $\begin{array}{c}\text { Total } \\
\mathbf{N} \\
(\mu \mathrm{g} \cdot / \mathrm{ml} .)\end{array}$ & $\begin{array}{c}\text { Total } \\
\text { sialic acid } \\
(\mu \mathrm{g} . / \mathrm{ml} .)\end{array}$ & $\begin{array}{c}\text { HI titre } \\
\text { v. } \\
\text { heated Roв }\end{array}$ & $\begin{array}{c}\text { Specitic } \\
\text { activity } \\
\mathrm{HI} / \mu \mathrm{g} . \\
\mathrm{N} / \mathrm{ml} \text {. }\end{array}$ \\
\hline 1 & $\mathbf{A}$ & 0.2 & $\begin{array}{l}\mathbf{0} \\
\mathbf{2}\end{array}$ & $\begin{array}{l}\text { n.t. } \\
\text { n.t. }\end{array}$ & $\begin{array}{l}\text { n.t. } \\
\text { n.t. }\end{array}$ & $\begin{array}{l}650 \\
153\end{array}$ & - \\
\hline 2 & D & 0.5 & $\begin{array}{l}\mathbf{0} \\
\mathbf{2}\end{array}$ & $\begin{array}{l}380 \\
200\end{array}$ & $\begin{array}{l}360 \\
200\end{array}$ & $\begin{array}{l}3850 \\
1930\end{array}$ & $\begin{array}{l}11 \\
10\end{array}$ \\
\hline 3 & $\mathbf{D}$ & $\begin{array}{l}0.1 * \\
0 \cdot 1 *\end{array}$ & $\begin{array}{l}\mathbf{0} \\
\mathbf{2}\end{array}$ & $\begin{array}{l}88 \\
74\end{array}$ & $\begin{array}{l}82 \\
72\end{array}$ & $\begin{array}{l}1538 \\
1472\end{array}$ & $\begin{array}{l}17 \\
20\end{array}$ \\
\hline 4 & $\mathbf{D}$ & 1 & $\begin{array}{l}\mathbf{0} \\
\mathbf{2} \\
\mathbf{6}\end{array}$ & $\begin{array}{l}860 \\
580 \\
260\end{array}$ & $\begin{array}{l}800 \\
560 \\
210\end{array}$ & $\begin{array}{r}7885 \\
4480 \\
344\end{array}$ & $\begin{array}{l}9 \\
8 \\
1 \cdot 3\end{array}$ \\
\hline 5 & D & 1 & $\begin{array}{l}0 \\
2 \\
6\end{array}$ & $\begin{array}{l}980 \\
480 \\
240\end{array}$ & $\begin{array}{l}800 \\
350 \\
250\end{array}$ & $\begin{array}{r}4070 \\
730 \\
90\end{array}$ & $\begin{array}{l}4 \\
1 \cdot 7 \\
0 \cdot 4\end{array}$ \\
\hline 6 & C & $1 \cdot 5$ & $\begin{array}{l}0 \\
2 \\
7 \frac{1}{2}\end{array}$ & $\begin{array}{r}1040 \\
460 \\
288\end{array}$ & $\begin{array}{r}1050 \\
510 \\
300\end{array}$ & $\begin{array}{r}20480 \\
3635 \\
160\end{array}$ & $\begin{array}{l}20 \\
8 \\
0 \cdot 5\end{array}$ \\
\hline
\end{tabular}

* Both the original material and centrifugal supernatant lyophilized and made up as $0 \cdot 1 \%$ solutions; n.t. $=$ not tested.

\section{Inhibitor activity}

Crude extracts, ammonium sulphate precipitates and ultracentrifuge supernatant fluids were tested for haemagglutination inhibition activity against prototype virus strains. Our earliest preparations were tested against heated Rов (B) 


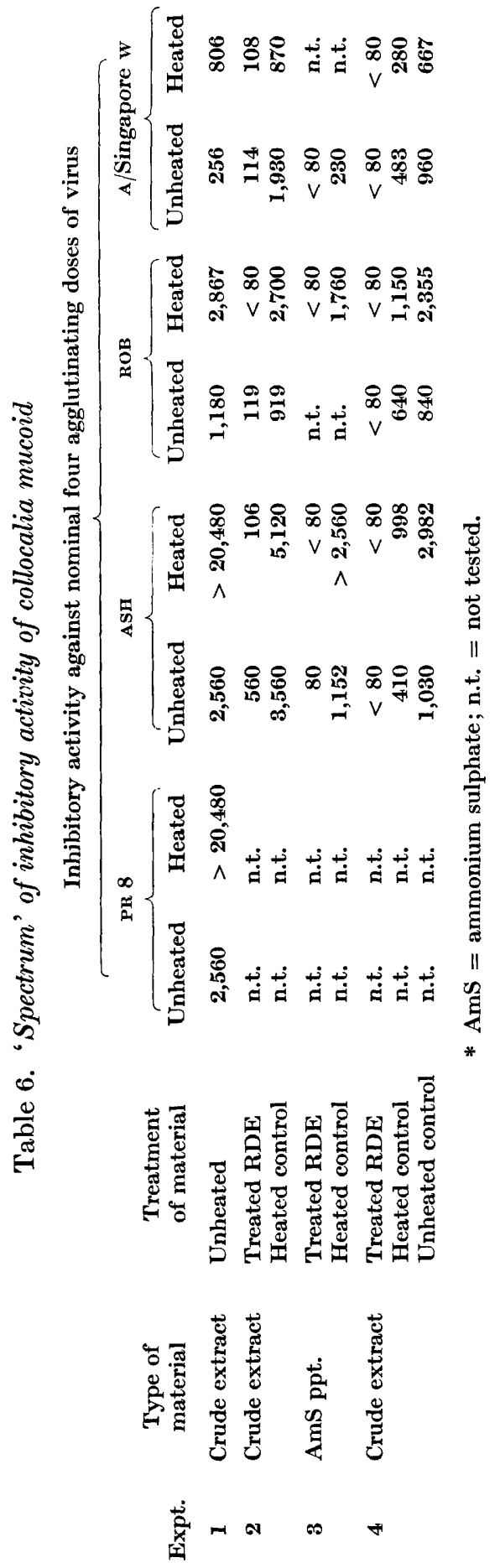


virus and, as already seen, were potent haemagglutination inhibitors of this strain. We also found that this activity was destroyed by neuraminidase with the accompanying release of sialic acid. It seemed therefore that this substance possessed classical $\alpha$ inhibitory activity. More extensive examination showed that it was active against a wide range of unheated virus strains. The results of these experiments are summarized in Table 6. The apparent loss of inhibitory activity of the collocalia mucoid when heated as a control preparation for the tests of neuraminidase sensitivity was found to be due to the presence of the acetate ions in the buffer used. It may be noted that collocalia mucoid is active against the heated and the unheated prototype viruses to varying degrees, maximal activity against an unheated strain being found with the Al strain ASH. The material left after centrifuging away the fast-moving $20 \mathrm{~S}$ component as described above was tested against the same virus strains (see Table 6 ) and exhibited a similar pattern of activity. Tests against selected strains suggested that this pattern of inhibitory activity against unheated virus was paralleled by the spectrum of neutralizing activity in ovo. It was found that maximal activity was exhibited against the type A 1 strain ASH, $1 \mu \mathrm{g}$. of the collocalia mucoid being sufficient to neutralize 1000 EID 50 of virus.

\section{DISCUSSION}

The data given here suggest that collocalia mucoid obtained by a simple process of extraction is not homogeneous, but the nature of its inhomogeneity is worthy of further discussion. The three peaks seen in the analytical ultracentrifuge suggest the presence of three substances with different molecular weights. All attempts to separate these by various chemical fractionation methods were unsuccessful, except in the earlier chromatographic studies when two components were separated, the second having a much greater specific activity than the first. However, no detailed study of this component could be made since it became inactivated on concentration. The full significance of these findings therefore remains obscure. The results of analytical ultracentrifugation indicated that some separation of the various components might be achieved on the preparative ultracentrifuge. It was shown subsequently that centrifugation of the crude material at $100,000 \mathrm{~g}$ for $2 \mathrm{hr}$. removed the bulk of the fast-moving $(20 \mathrm{~S})$ component as verified in the analytical ultracentrifuge, and left behind the slow-moving (1.4S and $4.7 \mathrm{~S})$ components. Examination of the freeze-dried material from the supernatant fluid showed that the nitrogen, sialic acid, and inhibitor values were equal to that of the whole; but more prolonged centrifugation for $6 \mathrm{hr}$., which must inevitably have isolated the slowest moving component, yielded a substance having a very low specific inhibitor activity. Thus it would appear that each of the three different molecular species possessed different biological activities. It was considered possible that the two slow-moving peaks resulted from a breakdown of a single substance, occurring under the influence of the centrifugal force, one fragment carrying the bulk of the activity. Against this hypothesis is the finding that low-temperature extraction of the original bird-nest material gave a substance with a very low inhibitory activity and which; on preliminary examination in the analytical ultracentrifuge appeared to have a low rate of sedimentation corresponding to the slowest moving peak seen in the crude extracts. It is likely from this that three physically (and probably biologically) different 
substances are present in the original crude preparation. About the electrophoresis studies it is difficult to arrive at any firm conclusions at this stage, except to say that whatever the differences between the three physically different components already discussed, they do not appear to differ in respect of the charges carried by them.

The picture just presented of the inhomogeneity of collocalia mucoid is made more interesting by the nitrogen and sialic acid values of the centrifugally separated components. The ratio of these values was fairly constant, irrespective of whether the material examined was a crude extract, that resulting from attempts at chemical fractionation, or the components obtained by ultracentrifugation. This constant relationship suggests a common chemical structure independent of physical inhomogeneity and this may be the result of depolymerization of a single large molecule. However, this can only be proved when the various components have been isolated in pure form, and for this reason a full chemical investigation was not carried out at this stage. Howe et al. (1961) reported a detailed chemical analysis of collocalia mucoid but gave no indication about the degree of homogeneity of their material. In the absence of any specific information about this point, and in view of our own findings, their results cannot be properly assessed, particularly as regards the relationship between the inhibitor properties and the chemical structure of collocalia mucoid.

The sensitivity of collocalia mucoid haemagglutination inhibitor to the action of neuraminidase, and its activity against the haemagglutinin of heated type $B$ virus strains, classes it by definition, as an $\alpha$ type inhibitor. It has been shown, however, to have a wide range of haemagglutination inhibiting action against other strains including the Al strain ASH, in the unheated state. The ability of collocalia mucoid to inhibit the haemagglutinin of an unheated virus is paralleled by its active neutralization of infectivity of the corresponding strain. Thus both strain AsH; and A/Singapore are readily neutralized, whereas unheated Rов is only weakly so. The demonstrable inhomogeneity of collocalia mucoid might suggest that this wide spectrum of activity against strains other than the heated type B strain RoB was due to the presence of a mixture of inhibitory substances. This is clearly refuted, however, by the very similar range of haemagglutination inhibition shown by the supernatant fluid after centrifugation at $100,000 \mathrm{~g}$ for $2 \mathrm{hr}$, under which conditions the bulk of the $20 \mathrm{~S}$ component was sedimented. Extending the period of centrifugation under these conditions to $6 \mathrm{hr}$. leaves a slowly sedimenting component which has very little inhibitory activity and thus presumably contributes little to the activity of the whole. It seems reasonable, therefore, to regard each of the distinguishable and biologically active molecular species of collocalia mucoid as carrying the same 'spectrum' of inhibitory activity; a conclusion further supported by the fact that the activity against all sensitive strains is more or less proportionately destroyed by neuraminidase.

The breadth of inhibitor 'spectrum' exhibited by this material is of some interest, when compared with the highly purified $\alpha$ type inhibitor prepared by Pusztai \& Morgan (1961) from ovarian cyst fluid. This latter material is not active in the haemagglutination inhibition test against representative unheated type A, A 1, A 2, and $B$ viruses, the whole of its inhibitory potency being directed against the heated (indicator) type B strains. Against such a strain it is as active, weight for weight, as 
collocalia mucoid. There seems a clear indication here that differences in the range of inhibitory action observed amongst haemagglutination inhibitors of the $\alpha$ type may be dependent on variations of molecular structure and chemical constitution, and that the property of neuraminidase sensitivity defines a chemically heterogeneous group of substances. Comparative investigations by other workers has already produced results to suggest that this is probably so (Gottschalk \& Fazekas de St Groth, 1960). The presence of a small molecular component in collocalia mucoid, which has a similar sialic acid/nitrogen ratio to that found for the other faster sedimenting components, but only about a tenth of their specific inhibitor activity, raises an interesting question regarding the importance of sialic acid to the $\alpha$ inhibitory activity of a mucoprotein molecule. An elucidation of this problem clearly awaits the separation and purification of the molecular components found in collocalia mucoid.

We should like to acknowledge the assistance of Mr F. Clothier of the M.R.C Virus Research Unit, Carshalton, and of Mr F. Ward of the Biochemistry Department, University College London, in carrying out the ultracentrifuge studies, and also the Wellcome Trust for providing us with the money to purchase necessary apparatus at a critical stage in these investigations.

\section{REFERENCES}

Belyavin, G., Westwood, J. C. N., Please, N. W. \& Smrth, W. (1951). Influenza haemagglutination: an evaluation of the photoelectric titration method. J. gen. Microbiol. $5,546$.

Burnet, F. M. \& Stone, J. D. (1947). The receptor destroying enzyme of $V$. cholerae. Aust. J. exp. Biol. Med. Sci. 25, 227.

Cohen, A. \& Belyavin, G. (1959). Haemagglutination inhibition of Asian virus; a new pattern of response. Virology, 7, 59-74.

Gottschalk, A. \& Fazekas De St Groth, S. (1960). On the relationship between the indicator profile and prosthetic group of mucoproteins inhibitory for influenza virus haemagglutinin. J. gen. Microbiol. 22, 690.

Hirst, G. K. \& Pickels, E. G. (1942). A method for the titration of influenza haemagglutinins and influenza antibodies with the aid of the photoelectric densitometer. J. Immunol. 45, 273.

Howe, C., Lee, L. T. \& Rose, H. M. (1960). Influenza virus sialidase. Nature, Lond. 188, 251.

Howe, C., LeE, L. T. \& Rose, H. M. (1961). Collocalia mucoid: a substrate for myxovirus neuraminidase. Arch. Biochem. Biophys. 95, 512.

LIM, K. A. (1954). A nomogram for $50 \%$ end-point interpolations. J. Hyg., Camb. $52,397$.

Paul, J. (1958). Determination of the major constituents of small amounts of tissue. Analyst, 58, 37.

Pusztai, A. \& Morgan, W. T. J. (1961). Studies in Immunochemistry, 18. The isolation and properties of a sialomucopolysaccharide possessing blood group Le ${ }^{\text {a }}$ specificity and virus receptor activity. Biochem. J. 78, 135.

Shimojo, H., Sugrura, A., Aкao, Y. \& Enomoto, C. (1959). Study of a non-specific haemagglutination inhibitor of influenza A/Asian/57 virus. Bull. Inst. publ. Hlth, Tokyo, 7, 219.

Smith, W., Westwood, J. C. N. \& Belyavin, G. (1951). A study of four virus strains isolated in 1951. Lancet, ii, 1189.

Sober, H. A., Gutter, F. J., Wycoff, M. M. \& Peterson, E. A. (1956). Chromatography of proteins. II. Fractionation of serum protein on anion exchange cellulose. J. Amer. chem. Soc. 78, 756. 
Tamm, I. \& Horsfall, F. L. (1952). A mucoprotein derived from human urine which reacts with influenza, mumps and Newcastle disease virus. J. exp. Med. 95, 71 .

Thomson, W. R. (1947). Use of moving averages and interpolation to estimate median effective dose. Bact. Rev. 11, 115.

Tiselius, A., HJertew, S. \& Levin, O. (1956). Protein chromatography on calcium phosphate columns. Arch. Biochem. Biophys. 65, 132.

WARrEn, L. (1959). The thiobarbituric acid assay of sialic acids. J. biol. Chem. 234, 1971. 